\title{
Demographic Factors Associated with Attitude of Youth Towards Agripreneurship
}

\author{
Mr. Mpheteli J. Malunga \\ Department of Statistics and Demography \\ National University of Lesotho \\ P.O. Roma, 180, Lesotho \\ Mr. Bukenya M. Patrick \\ Department of Business Administration \\ National University of Lesotho \\ P.O. Roma, 180, Lesotho \\ Dr. Regina M. Thetsane \\ Department of Business Administration \\ National University of Lesotho \\ P.O. Roma, 180, Lesotho \\ Dr. Motšelisi C. Mokhethi \\ Department of Business Administration \\ National University of Lesotho \\ P.O. Roma, 180, Lesotho
}

\begin{abstract}
Agricultural entrepreneurship especially among youth is essential for employment creation. Entrepreneurial attitude is identified asa key driver to agricultural entrepreneurship and it seems to be associated with demographic factors. Research results on demographic factors still require further research which necessarily add more insight to the area of study. Hence the present study is aimed at evaluating the entrepreneurial attitude of youth in Lesotho and demographic factors that could have an influence on such attitude. A quota convenience sampling technique was used to select a sample from the National University of Lesotho final year undergraduates which resulted in attaining 78.8 percent response rate. A structured questionnaire was used for data collectionwhile descriptive statistics was used for data analysis. The results demonstrated that the majority of youth exhibited a negative attitude towards agricultural entrepreneurship therebysignifying the need for interventions that would ignite positive attitude to motivate agriculturalentrepreneurial activity in the country.All demographic factors with the exception ofone werefound to be significant predictors of entrepreneurial attitudeinherently useful in segmenting youth market if entrepreneurial interventions are implemented.
\end{abstract}

Keywords: Agriculture entrepreneurship, entrepreneurial attitude, Youth, demographic factors

\section{Introduction}

The economic output in Lesotho has been strongly supported by the tertiary sector followed by secondary sector over the years as reflected in Table 1. On the other hand, the primary sector especially agriculture sector has not been performing well despite a significant growth of 17.1 in 2013 as shown in Table 1. 
Table 1: Domestic Economic Outlook

\begin{tabular}{|c|c|c|c|c|c|c|}
\hline & \multicolumn{3}{|l|}{ Actuals } & \multicolumn{3}{|c|}{ Projections } \\
\hline & 2012 & 2013 & 2014* & 2015 & $\begin{array}{l}201 \\
6\end{array}$ & 2017 \\
\hline Economic growth & 5.0 & 4.6 & 3.8 & 3.3 & 3.2 & 5.7 \\
\hline Primary sector & 0.5 & 6.3 & 2.9 & 0.6 & 8.8 & 10.4 \\
\hline Agriculture and related & -13.8 & 17.1 & 0.7 & 1.8 & 2.2 & 2.6 \\
\hline Mining and quarrying & 22.6 & -5.3 & 5.8 & -1.1 & 17.5 & 19.2 \\
\hline Secondary sector & 4.7 & 1.6 & 0.8 & 0.8 & -3.4 & 5.0 \\
\hline Textile and clothing & -5.6 & -13.9 & -6.9 & -6.4 & -6.3 & -6.2 \\
\hline Building and construction & 24.6 & 21.5 & 10.7 & 3.4 & -8.8 & 13.2 \\
\hline Tertiary/Services sector & 5.9 & 5.4 & 5.3 & $\mathbf{5 . 0}$ & 4.6 & 4.8 \\
\hline Wholesale and retail & 12.5 & 10.2 & 8.2 & 10.4 & 6.7 & 7.5 \\
\hline Transport and communication & 5.5 & 5.6 & 6.3 & 8.4 & 8.6 & 8.7 \\
\hline Financial services & 7.1 & 16.1 & 6.3 & 9.0 & 7.6 & 7.5 \\
\hline $\begin{array}{l}\text { Real estate and Business } \\
\text { services }\end{array}$ & 4.4 & 2.1 & 2.9 & 2.1 & 3.1 & 3.1 \\
\hline
\end{tabular}

*Estimate Source: Central Bank. (2015)

The contribution of Agriculture, Forestry and Fishing (AFF) to the Gross Domestic Product (GDP) gradually continues to decline since 1995 from 12 percent to 7 percent of GDP in the period 2010-2014 (Table 2).

Table 2: Agriculture, Forestry and Fishing (AFF), GDP, 5-Year averages, 1995-2014

\begin{tabular}{|l|r|r|r|r|}
\hline Industry & $\mathbf{1 9 9 5 - 1 9 9 9}$ & $\mathbf{2 0 0 0 - 2 0 0 4}$ & $\mathbf{2 0 0 5 - 2 0 0 9}$ & $\mathbf{2 0 1 0 - 2 0 1 4}$ \\
\hline $\begin{array}{l}\text { Agriculture, forestry and fishing (\% of } \\
\text { total GDP) }\end{array}$ & $775(12)$ & $785(10)$ & $683(8)$ & $808(7)$ \\
\hline $\begin{array}{l}\text { Growing of crops; horticulture (\% of } \\
\text { AFF GDP) }\end{array}$ & $303(39)$ & $285(36)$ & $176(26)$ & $207(26)$ \\
\hline Farming of animals (\% of AFF GDP) & $352(45)$ & $390(50)$ & $398(58)$ & $423(52)$ \\
\hline $\begin{array}{l}\text { Agricultural service activities (\% of } \\
\text { AFF GDP) }\end{array}$ & $68(9)$ & $54(7)$ & $41(6)$ & $44(5)$ \\
\hline Forestry (\% of AFF GDP) & $52(7)$ & $55(7)$ & $68(10)$ & $133(16)$ \\
\hline GDP at Purchaser's prices & 6,500 & 7,544 & 8,982 & 11,274 \\
\hline
\end{tabular}

Source: United Nations Development Programme (UNDP). (2017).

Although agriculture sector is not performing well it remains an important livelihood activity to the significant proportion of Lesotho population especially in the rural areas (UNDP, 2017). According to Sullivan (2017) agriculture sector is twice as effective in reducing poverty as does any other sector because as productivity increases in the sector, food prices will correspondingly reduce and the disadvantage people will then benefit.In agreement, Sichone and Kwenye (2018) note that agriculture plays a major role in both the economic growth and development of most countries, and therefore interest has to be developed around the sector especially among the youth. According to the aforementioned authors the young population is the ideal catalysts for agriculture development because of their resilience, perseverance, willingness to adapt to new ideas, willingness to adapt to new technologies which are the essential attributes necessary to transform agriculture sector.

\section{Problem statement}

Lesotho has a high unemployment rate averaged at 25.3 percent but youth category defined as persons aged between 15 and 35 years is the hardest hit by the scourge where unemployment ranges between 30 and 33 percent (UNDP, 2012; Shale, 2013; UNDP, 2017). According to Ekpoh and Edet (2011) university graduates are not immune from the problem of unemployment and this is all the more so because the period between graduation and employment dates is increasingly becoming longer. According to Ridha, Wahyu, B and Wahyu, B.P (2017) on a yearly basis, colleges inject graduates into the labor market and due to lack of employment opportunities the very positive contribution of colleges is translated into anincrease in unemployment rate. The challenge of unemployment can be tackled by growing the economy and generating employment. Entrepreneurship is considered a suitable vehicle for both economic and job growth (Aaijaz\& Ibrahim, 2013; Azila-Gbettor\& Harrison, 2013; Radipere, 2012; Nieman\&Nieuwenhuizen, 2009; 
Idogho \& Augustine, 2011; Oyewuni \& Olufemi, 2013; Buttar, 2015; Boateng, G.O., Boateng, A.A. \& Bampoe, 2014; Rauch \& Hulsink, 2015; Abebe, 2015).

Agricultural entrepreneurship is regarded beneficial to the youth because it can be a means of employment creation that can also benefit a country as a whole by improving food supply, overcome poverty and reduce the country's reliance on food imports and ensure food security (Nor, Masdek \& Maidin, 2015; Ekpoh \& Edet, 2011; Gwary et al, 2011). However, agriculture sector is still considered secondary to other sectors for self-employment, especially among the youth and persons with tertiary education, as it is regarded a rough job, less rewarding and with few future prospects (Abdullah, A.A. \& Sulaiman, 2013).

Over and above that, agriculture sector in some countries including Lesotho are faced with numerous challenges, such as, unfavourable weather conditions and limited access to finance, to mention but a few, that weigh heavily on production in the sector (Central Bank of Lesotho, 2015).

Furthermore, arable land in Lesotho is only 10 percent as the country is mostly mountainous and the arable land gradually continues to decline due to the increasing tendency of using arable land for non-agricultural purpose (UNDP, 2017; Damane \& Sekantsi, 2018, Central Bank of Lesotho, 2015). Generally, also there is a noticeable continual decline of youth interest in agricultural sector where youngsters, even those who are agriculture specialists, prefer jobs in other sectors (Abdullah, A.A. \& Sulaiman, 2013; Ridha, R.N. et al, 2017). A number of factors that influence youth interest to become agriculture entrepreneurs have been identified. According to Oyewumi and Olufemi (2013) attitude is assumed to be a better explanatory factor for a career choice, thus, a positive entrepreneurial attitude towards agriculture is a reliable predictor that one is likely to choose to be an agriculture entrepreneur.

Baliyan, S.P and Baliyan, P.S (2018) indicate that the most important step to identify hindrances to entrepreneurial interest among youth is to understand the factors influencing attitude towards entrepreneurship. According to the authors understanding factors influencing attitude will uncover barriers to entrepreneurship and self-employment. As Lesotho is faced with the declining agriculture entrepreneurship interest among youth, it is important to assess their attitude and factors influencing such attitude. Demographic factors (e.g. gender, age, income, marital status, work experience, locality, family background and ethnicity) have been studied to determine whether they have an impact on attitude (Nishantha, 2009; D'Silva et al, 2010; Baliyan, S.P \& Baliyan, P.S., 2018; Tamizharasi \& Panchanatham, 2010). The findings regarding the influence of demographic factors to attitude give varying results, hence the study is aimed at evaluating the entrepreneurial attitude of youth in Lesotho and factors that have an influence on such attitude. The study will therefore answer the following research questions:

- What is the attitude of Lesotho's youth towards agriculture entrepreneurship?

- What is the association of the selected demographic factors to the attitude of Lesotho's youth towards agriculture entrepreneurship?

\section{Literature review}

Entrepreneurship has become one of the main alternatives for students after they graduate (Ekpoh\&Edet, as cited in Abebe, 2015). However, there is no consensus on the potential of agriculture entrepreneurship among youth. Aman et al (2017) are of the view that agriculture sector has the prospects to be the most dominant sector of employment for the youth for some decades to come. Nor, et al, (2015) are of the view that agricultural entrepreneurship has the potential to be developed among youth. On the other hand, Amadi (2012) indicates that the youth have negative perceptions about agriculture and would rather migrate to urban cities for white color jobs that are regarded less laborious and hygienic and opt to leave agriculture in the hands of the old illiterate parents. Even for the youth that engage in agriculture sector, they consider it as a temporary solution for unemployment problem while they pursue other better alternatives (Abdullah, A.A.\&Sulaiman, 2013).

Given that it is not easy to attract youth to become agriculture entrepreneurs it is important to determine factors that influence youth to opt for that career path. A number of factors were identified as shown in Table 3 . 
Table 3: Factors Influencing Inclination towards Agriculture Entrepreneurship

\begin{tabular}{|l|l|l|}
\hline$\#$ & Factor & Authors \\
\hline 1 & Attitude & $\begin{array}{l}\text { Sa'adiah, Mahshar, Sulai, Rosli \& Hamzah (2019); } \\
\text { Abdullah, F.A.\& Samah (2014); Tshikovhi \& Shambare (2015); } \\
\text { Uli, D'Silva, Shaffril \& Samah (2010); } \\
\text { Abdullah, A.A. \& Sulaiman (2013) }\end{array}$ \\
\hline 2 & Subjective norms & $\begin{array}{l}\text { Tshikovhi \& Shambare (2015); Abdullah, F.A. \& Samah (2014); } \\
\text { Ridha, R.N.,Burhanuddin \& Wahyu (2017) }\end{array}$ \\
\hline 3 & Behavioural control & Tshikovhi \& Shambare (2015) \\
\hline 4 & $\begin{array}{l}\text { Entrepreneurial } \\
\text { knowledge }\end{array}$ & $\begin{array}{l}\text { Tshikovhi \& Shambare (2015); Uli et al (2010); } \\
\text { Abdullah, A.A. \& Sulaiman (2013) }\end{array}$ \\
\hline 5 & Support & Uli et al (2010); \\
\hline 6 & Belief & Uli et al (2010); \\
\hline 7 & Social valuation & Abdullah, F.A. \& Samah (2014) \\
\hline 8 & Acceptance & Abdullah, A.A. \& Sulaiman (2013) \\
\hline 9 & $\begin{array}{l}\text { Personality traits (risk } \\
\text { taking and } \\
\text { innovativeness) }\end{array}$ & Aman, Rahim, Kushairi \& Fansuri (2017) \\
\hline
\end{tabular}

Source: Authors compilation

All authors agree on personal attitude as a factor that influences inclination or interest towards agriculture entrepreneurship. According to Oyewumi and Olufemi (2018) and Abdullah, A.A. and Sulaiman's (2013) the interest of youth to become agriculture entrepreneurs is based predominantly on their attitude and voluntary acceptance without coercion from any party. Attitude refers to an individual's degree of like or dislike for something (D'Silva, et al, 2010). According to Uli, et al (2010), a positive attitude towards an activity results in an individual's willingness to engage in such an activity.

In order to influence positive entrepreneurial attitudes, it is important to understand factors that contribute to the development of the attitudes (Baliyan, S.P \& Baliyan, P.S. 2018). Socio-economic/demographic and personality traits have been found to be the predictors of entrepreneurial attitude. Studies, however, provide varying results as shown in Table 4.

Table 4: Factors that Influence Entrepreneurial Attitude

\begin{tabular}{|c|c|c|c|}
\hline$\#$ & Authors & Factors studied & $\begin{array}{l}\text { Factors confirmed to be a predictor } \\
\text { of attitude }\end{array}$ \\
\hline 1 & $\begin{array}{lr}\text { Baliyan, } & \text { S.P \& } \\
\text { Baliyan, } & \text { P.S. } \\
\text { (2018) } & \end{array}$ & $\begin{array}{l}\text { gender, } \\
\text { program of study, } \\
\text { year of study, } \\
\text { mothers level of education, } \\
\text { mother's profession, } \\
\text { family income } \\
\text { student career ambition after completion of } \\
\text { degree program } \\
\text { parents career ambition after completion of } \\
\text { degree program }\end{array}$ & $\begin{array}{l}\text { program of study, } \\
\text { year of study, } \\
\text { mothers level of education, } \\
\text { student career ambition after } \\
\text { completion of degree program }\end{array}$ \\
\hline 2 & $\begin{array}{l}\begin{array}{l}\text { D'Silva et } \\
\text { (2010) }\end{array} \\
\end{array}$ & $\begin{array}{l}\text { gender } \\
\text { locality } \\
\text { agriculture background } \\
\text { information in agriculture } \\
\text { type of courses taken } \\
\text { the university where one is studying } \\
\text { age } \\
\text { monthly expenditure }\end{array}$ & $\begin{array}{l}\text { information } \\
\text { type of courses taken } \\
\text { the university where one is studying }\end{array}$ \\
\hline 3 & $\begin{array}{l}\text { Tamizharasi \& } \\
\text { Panchanatham } \\
\text { (2010) }\end{array}$ & $\begin{array}{l}\text { age } \\
\text { income } \\
\text { marital status }\end{array}$ & $\begin{array}{l}\text { age } \\
\text { income }\end{array}$ \\
\hline
\end{tabular}




\begin{tabular}{|c|c|c|c|}
\hline & & type of ownership of the enterprise & \\
\hline 4 & Nor et al (2015) & $\begin{array}{l}\text { gender } \\
\text { locality } \\
\text { marital status } \\
\text { courses studied } \\
\text { entrepreneurship) } \\
\text { agricultural background } \\
\text { father occupation } \\
\text { mother's occupation } \\
\text { knowledge in the agriculture sector } \\
\text { facilities provided by government } \\
\text { the role of government in promoting the } \\
\text { agriculture sector } \\
\text { risks in agricultural enterprises }\end{array}$ & $\begin{array}{l}\text { gender } \\
\text { father occupation (self-employment } \\
\text { significant) } \\
\text { agriculture background } \\
\text { courses studied (in particular having } \\
\text { studied entrepreneurship course) } \\
\text { marital status (single individuals found } \\
\text { to have high attitude towards } \\
\text { entrepreneurship) } \\
\text { knowledge in the agriculture sector } \\
\text { the role of government in promoting } \\
\text { the agriculture sector } \\
\text { risks in agricultural enterprises }\end{array}$ \\
\hline 5 & Nishantha (2009) & $\begin{array}{l}\text { age } \\
\text { gender } \\
\text { self-employment work experience } \\
\text { occupation of parents } \\
\text { internal locus of control } \\
\text { risk taking propensity } \\
\text { need for achievement }\end{array}$ & $\begin{array}{l}\text { gender } \\
\text { risk taking propensity } \\
\text { need for achievement }\end{array}$ \\
\hline
\end{tabular}

\section{Source: Authors compilation}

Literature as shown in Table 4 reflects the inconsistencies with regards to demographic variables that influence entrepreneurial attitude. Different studies have focused on different variables and as such, providing varying results and even for common variables the studies have come up with different results. For instance, age was found to be significant in Tamizharasi and Panchanatham (2010)'s study while it was insignificant in D'Silva et al (2010). Based on the literature review, the following research hypotheses were formulated for the following demographic variables, gender, agriculture background, location, age and program of study:

$\mathrm{H}_{10}$ : The attitude of Lesotho's youth towards agriculture entrepreneurship is not associated to gender

$\mathrm{H}_{1 \mathrm{a}}$ : The attitude of youth towards agriculture entrepreneurship is associated to gender

$\mathrm{H}_{2 \mathrm{o}}$ : The attitude of Lesotho's youth towards agriculture entrepreneurship is not associated to having agriculture background

$\mathrm{H}_{2 \mathrm{a}}$ : The attitude of youth towards agriculture entrepreneurship is associated to having agriculture background

$\mathrm{H}_{30}$ : The attitude of Lesotho's youth towards agriculture entrepreneurship is not associated to the locality one grew at

$\mathrm{H}_{3 \mathrm{a}}$ : The attitude of youth towards agriculture entrepreneurship is associated to the locality one grew at

$\mathrm{H}_{4 \mathrm{o}}$ : The attitude of Lesotho's youth towards agriculture entrepreneurship is not associated to age

$\mathrm{H}_{4 \mathrm{a}}$ : The attitude of youth towards agriculture entrepreneurship is associated to age

$\mathrm{H}_{5 \mathrm{o}}$ : The attitude of Lesotho's youth towards agriculture entrepreneurship is not associated to program of study

$\mathrm{H}_{5 \mathrm{a}}$ : The attitude of youth towards agriculture entrepreneurship is associated to program of study

\section{Methodology}

The paper adopted a descriptive research design following a quantitative approach. It aimed to determine the attitude of youth towards agriculture entrepreneurship and the demographic factors that influence that level of attitude. The study setting of the National University of Lesotho (NUL) was chosen because universities are regarded as places where entrepreneurial cultures and aspirations are shaped (Baliyan, S.P \&Baliyan, P.S 2018). A non-probability quota sampling was adopted that set a proportion for the final year registered students in each faculty to determine the target sample. There were 1427 final year registered students as per the records of the university. Sekaran and Bougie's (2013) table of sample size was used and a sample of 306 for the population size of 1427 was adopted. There were 241 respondents that provided useable responses translating into 78.8 percent response rate.

Liñán's (2004) questionnaire was adopted and modified to fit the agriculture context. The instrument was divided into two sections where the first sections focused on demographic questions and the second section was centred on questions meant to reveal the attitude of the respondents towards agriculture career. The attitude scale was measured on a five-point likert scale. 


\section{Findings and Discussion}

\subsection{Demographic analysis}

Table 5 reflects the demographic data of the respondents that were studied. It is shown in the results that the female respondents are slightly over half of the respondents ( 58.7 per cent) with the reminder of 41.1 percent attributable to male respondents. The results portray the situation at higher institutions in Lesotho as there are more females enrolled than males. According to Council on Higher Education (CHE) (2017), in the period 2014-2015, 59.8 per cent of students enrolled in higher institutions in Lesotho were females and 40.2 per cent were males. In the same period gender proportions at the NUL was 62.9 per cent females and males was 37.1 per cent. The majority of students are in the category of $18-25$ years of age (64.7 per cent). The results also portray the status at the university where CHE (2017) shows that the largest category at the NUL in 2014/2015 was between 20 and 24 years.

Regarding the faculties, it is noted that the majority of students are from the Faculty of Social Sciences (39.4 per cent). The study adopted quota sampling as a result the bigger the faculty the larger was its proportion to the sample. The smallest faculties are Health and Law in that order unfortunately the researcher attained zero response from the Faculty of Health. The large percentage of respondents (61.0 per cent) indicated that they had agriculture background.

According to Rocchi and Del Sette (2016) agriculture is the way of life for the majority of Basotho where around 70 per cent of the population relies on farming of which 90 percent are subsistence farmers. It explains why most students have agriculture background as possibly they were exposed to farming from their family setting. The large percentage of respondents (54.4 per cent) is born in the rural areas. However, the number of respondents that grew up in the rural areas is 41.5 per cent and this is no surprise as commonly countries experience mass migration of youth to urban centres (Amadi, 2012). The question on parent's occupation was not well responded to as 29.9 percent was left blank, but the majority of the responses showed that parents are mostly self-employed and for parents of muscular gender that will duly contribute towards a positive influence towards entrepreneurship attitude.

Table 5: Demographic Results of Respondents

\begin{tabular}{|l|l|l|}
\hline Variables & Frequency & Percentage \\
\hline Gender & & \\
Male & 99 & 41.1 \\
Female & 142 & 58.9 \\
\hline Age & & \\
$18-25$ & 156 & 64.7 \\
$26-30$ & 64 & 26.6 \\
$31-35$ & 20 & 8.3 \\
36 and above & 1 & .4 \\
\hline Faculty & & \\
Social Sciences & 95 & 39.4 \\
Education & 20 & 8.3 \\
Agriculture & 29 & 12.0 \\
Humanities & 55 & 22.8 \\
Science and Technology & 30 & 12.4 \\
Law & 12 & 5.0 \\
Health Sciences & - & - \\
\hline Agriculture Background & & \\
Have & 147 & 61.0 \\
Do not have & 93 & 38.1 \\
Missing & 1 & .4 \\
\hline Region one is born in & & \\
Rural & 131 & 54.4 \\
Urban & 106 & 43.9 \\
Missing & 4 & 1.7 \\
\hline Region one mostly grew in & & \\
Rural & 100 & 41.5 \\
Urban & 136 & 56.4 \\
Missing & 5 & 2.1 \\
\hline
\end{tabular}




\begin{tabular}{|l|l|l|}
\hline Parent/guardian occupation & \\
Self-employed & 98 & 40.7 \\
Hired & 71 & 29.5 \\
Missing & 72 & 29.9 \\
\hline
\end{tabular}

\section{Source: Authors compilation}

\subsection{Descriptive analysis}

Entrepreneurial attitude was measured using three items as shown in Table 6. The results indicate that 35.3 per cent of the respondents agreed that their prospects of being agriculture entrepreneurs against being employees is high, while 30 per cent of the respondents agreed that agriculture entrepreneurship is their preferred career option immediately after completing their studies. The results further reveal that 23 per cent of the respondents agreed that agriculture is their preferred career of all times (Table 6). Considering the responses, it is obvious that the majority of the respondents seem not to agree with these three items. The pooled value of the mean and standard Deviations for entrepreneurial attitude indicate that the respondents had negative attitude (mean=2.84, SD=1.157) towards agriculture entrepreneurship. This result shows that there is dire need for a lot of effort focused on youth to change the negative entrepreneurial attitude.

Table 6: Distribution of the Perceptions of Respondents on Entrepreneurial attitude

\begin{tabular}{|l|l|l|l|l|l|l|l|l|}
\hline Items & $\mathbf{N}$ & $\begin{array}{l}\text { Strongly } \\
\text { disagree }\end{array}$ & Disagree & Moderate & Agree & $\begin{array}{l}\text { Strongly } \\
\text { agree }\end{array}$ & Mean & SD \\
\hline Prospects & 238 & 11.3 & 14.7 & 38.7 & 14.3 & 21.0 & 3.19 & 1.247 \\
\hline Career after studies & 240 & 22.5 & 23.3 & 24.2 & 13.3 & 16.7 & 2.78 & 1.376 \\
\hline Career all times & 239 & 26.4 & 29.3 & 20.5 & 10.0 & 13.8 & 2.56 & 1.346 \\
\hline
\end{tabular}

Source: Authors compilation

The t-test was conducted to make comparisons between entrepreneurial attitude and selected demographic variables, namely, gender, agriculture background, locality of respondents, age and program of study. The results in Table 7 indicated a statistically significant difference between males and females where females show a lower attitude (mean=2.54, $\mathrm{SD}=1.03$ ) compared with males (mean=3.27, $\mathrm{SD}=1.20)$. Therefore, null hypothesis $\left(\mathrm{H}_{1} \mathrm{o}\right)$ is rejected. Similarly, the results show a statistically significant difference between respondents with agricultural background and those without agricultural background on their entrepreneurial attitude. The respondents with agricultural background had higher attitude (mean=3.12, $\mathrm{SD}=1.12$ ) compared to those with no agricultural background (mean=2.40, $\mathrm{SD}=0.96)$. Therefore, null hypothesis $\left(\mathrm{H}_{2} \mathrm{O}\right)$ is rejected. The findings in this study are in line with other studies such as Nishantha (2009) and Nor et al (2015) who found significant results with respect to gender. Nor et al (2015) also found a relationship between entrepreneurial attitude and agriculture background.

On the other hand, the mean score of entrepreneurial attitude for respondents who grew up in the rural area (mean=3.13, SD=1.21) was found to be significantly different from the mean score of the respondent who grew up in the urban area (mean=2.61, $\mathrm{SD}=1.06)(\mathrm{t}=2.345, \mathrm{p}<0.05)$. This finding is not in line with findings in $\mathrm{D}$ 'Silva (2015), and Nor et al (2015) that found locality to be insignificant to entrepreneurial attitude. Given the t-test results for locality null hypotheses $\left(H_{3 o}\right)$ is rejected.

Table 7: Comparison of selected demographic variables to entrepreneurial attitude

\begin{tabular}{|l|l|l|l|l|}
\hline Factors & Mean & SD & t-value & p-value \\
\hline Attitude & 3.27 & 1.20 & & $0.9000^{*}$ \\
\hline Male & 2.54 & 1.03 & & \\
\hline Female & \multicolumn{2}{l|}{} & 5.163 & \\
\hline Attitude & 3.12 & 1.12 & & $0.000^{*}$ \\
\hline Have background & 2.40 & 0.96 & & \\
\hline No background & & 2.345 & $0.020^{*}$ \\
\hline Attitude & 3.13 & 1.21 & & \\
\hline Rural & 2.61 & 1.06 & & \\
\hline Urban & & & \\
\hline
\end{tabular}

Note: * significant at 0.05 .

Source: Authors compilation 
The results in Table 8 show that the entrepreneurial attitude of respondents aged $36+$ had the highest mean score (4.33) followed by those aged 31-35 (3.26) while those aged 18-25 came last with mean score of 2.73. A statistically insignificant differences between age and attitude $(\mathrm{F}=2.177, \mathrm{p}<0.05)$ isobserved (Table 9). These results indicate that age does not have a bearing on entrepreneurial attitude of respondents, therefore null hypotheses $\left(H_{40}\right)$ is not rejected.Tamizharasi and Panchanatham (2010) found age to be a significant factor towards entrepreneurial attitude while D'Silva et al (2010) and Nishantha (2009) found the same results where age is insignificant to entrepreneurial attitude.

Table 8: Means comparing ages of the respondents and entrepreneurial attitude

\begin{tabular}{|c|c|c|c|}
\hline Age & $\mathbf{N}$ & Mean & SD \\
\hline \multicolumn{4}{|c|}{ Attitude } \\
\hline $18-25$ & 156 & 2.73 & 1.11 \\
\hline $26-30$ & 63 & 2.96 & 1.19 \\
\hline $31-35$ & 20 & 3.26 & 1.28 \\
\hline $36+$ & 1 & 4.33 & \\
\hline
\end{tabular}

Source: Authors compilation

Table 9: Analysis of Variance comparing ages of the respondents and entrepreneurial attitude

\begin{tabular}{|l|l|l|l|l|l|}
\hline Source & Sum of Squares & df & Mean Square & F & P-value \\
\hline Attitude & 8.617 & 3 & 2.872 & 2.177 & 0.091 \\
\hline Between Groups & 311.341 & 236 & 1.319 & & \\
\hline Within Groups & 319.958 & 239 & & & \\
\hline Total & & & & \\
\hline
\end{tabular}

\section{Source: Authors compilation}

Finally, the results in Table 10 show the mean scores of the respondents' entrepreneurial attitude in the different faculties. The mean score of entrepreneurial attitude of respondents for the Faculty of Agriculture is the highest (4.39) followed by Education (3.13) while Social Sciences came last with 2.38.

Table 10: Means and Standard Deviations comparing entrepreneurial attitude for six Faculties.

\begin{tabular}{|l|l|l|l|}
\hline \multicolumn{2}{|l|}{ Faculty } & N & Mean \\
\hline Attitude & \multicolumn{2}{l|}{ SD } \\
\hline Social Sciences & 95 & 2.38 & 0.98 \\
\hline Education & 20 & 3.13 & 1.22 \\
\hline Agriculture & 29 & 4.39 & 0.82 \\
\hline Humanities & 55 & 2.87 & 1.01 \\
\hline Science and Technology & 29 & 2.50 & 0.97 \\
\hline Law & 12 & 2.84 & 0.25 \\
\hline
\end{tabular}

Source: Authors compilation

A statistically significant difference was found among the six faculties in terms of entrepreneurial attitude $(\mathrm{F}=18.990$, $\mathrm{p}<0.05$ ) (Table 11). These results indicate that students from different faculties differed in terms of attitude towards agriculture entrepreneurship.

Table 11: Analysis of variance comparing six faculties in terms of entrepreneurial attitude

\begin{tabular}{|l|l|l|l|l|l|}
\hline Source & Sum of Squares & df & Mean Square & F & P-value \\
\hline $\begin{array}{l}\text { Between } \\
\text { Groups }\end{array}$ & 92.356 & 5 & 14.741 & 18.990 & 0.000 \\
\hline Within Groups & 227.602 & 234 & 0.973 & & \\
\hline Total & 319.958 & 239 & & & \\
\hline
\end{tabular}

\section{Source: Authors compilation}

Having found statistically significant evidence that the mean scores of the respondents differ in the six faculties in terms of attitude towards agriculture entrepreneurship, Tukey HSD test was conducted to explore the differences among the six faculties. The results indicate that the significant statistical difference exist between the mean scores of 
students from the faculty of agriculture and the faculties of Law, Social Sciences, Science and Technology, Education and Humanities (Table 12). Baliyan, S.P and Baliyan, P.S (2018) in their study found a relationship between entrepreneurial attitude and program of study meaning that the results of this study are consistent with some previous studies.

Table 12: Comparisons of mean scores for Six Faculties in terms of entrepreneurial attitude

\begin{tabular}{|c|c|c|c|}
\hline \multirow[b]{2}{*}{ Faculty } & \multirow[b]{2}{*}{$\mathrm{N}$} & \multicolumn{2}{|c|}{ Subset for Alpha $=\mathbf{0 . 0 5}$} \\
\hline & & 1 & 2 \\
\hline \multicolumn{4}{|l|}{ Attitude } \\
\hline Social Sciences & 95 & 2.38 & \\
\hline Law & 12 & 2.50 & \\
\hline Science and Technology & 29 & 2.70 & \\
\hline Humanities & 55 & 2.87 & \\
\hline Education & 20 & 3.13 & \\
\hline Agriculture & 29 & & 4.38 \\
\hline P-value & & 0.071 & 1.00 \\
\hline
\end{tabular}

Source: Authors compilation

The findings show that majority of respondents have a negative entrepreneurial attitude towards agriculture entrepreneurship. The negative entrepreneurial attitude towards agriculture entrepreneurship exhibited by youth in Lesotho will influence entrepreneurial intentions negatively. Consequently, there will be fewer chances of agriculture entrepreneurs emerging among youth in Lesotho unless some measures are put in place to influence their attitude. On the other hand, the study has provided factors that contribute to the development of entrepreneurial attitude and this will be useful to policy makers as they would be able to use the variables for segmenting the youth market in Lesotho when they plan entrepreneurial interventions meant to influence entrepreneurial attitude.

\section{Conclusion}

The study revealed that entrepreneurial attitude significantly differs in accordance with gender, agriculture background, program studied, and locality, but not for age. Additionally, the study shows that Lesotho youth in general have a negative entrepreneurial attitude towards agriculture entrepreneurship. The negative attitude of Lesotho youth will affect the likelihood of youth starting own business in the sector. It is therefore recommended that programs that can ignite positive attitude among youth be put in place in order to motivate entrepreneurial activity in the country. The sector can also be promoted to encourage participation of youth and assistance be provided for those who opt to enter into the sector.

\section{References}

Aaijaz, N. \& Ibrahim, M.D.B. (2013). Influence of student's non-cognitive and cognitive traits on their proposed entrepreneurial ventures' initial set up decision. British Journal of Marketing Studies, 1(3):1-15

Abdullah, A.A. \& Sulaiman, N.N. (2013). Factors that influence the interest of youths in agriculture entrepreneurship, International Journal of Business and Social Science, 4(3):288-302

Abdullah, F.A. \& Samah, B.A. (2014). Factors influencing inclination towards agriculture entrepreneurship among students in agriculture learning institute., Asian Social Science, 10(2):273-278

Abebe, A. (2015). Attitude of undergraduate students towards self-employment in Ethiopian public Universities, International Journal of Business and Management Review, 3(7):1-10

Amadi, U.P.N. (2012). Agricultural entrepreneurship development for youth empowerment in Nigeria: Constraints and initiatives for improvement, Journal of Educational and Social Research, 2(10):107-114

Aman, Z., Rahim, A.R.A., Kushairi, A., \&Fansuri, E. (2017). Agribusiness entrepreneurial intention among Generation Y: The role of personality traits. International Journal of Advanced Biotechnology and Research, 8(Special Issue-3), 190-196

Azila-Gbettor, E.M. \& Harrison, A.P. (2013).Entrepreneurship training and capacity building of Ghanaian Polytechnic graduates.International Review of Management and Marketing, 3(3):102-111

Baliyan, S.P. \& Baliyan, P.S. (2018). Socio-economic factors as predictors of undergraduate students' attitude towards entrepreneurship in Botswana. Journal of Entreprneurship and Business Innovation, 5(1): 43-58

Boateng, G.O., Boateng, A.A. \& Bampoe, H.S. (2014). Barriers to youth entrepreneurship in rural areas of Ghana, Global Journal of Business Research, 8(3):109-119 
Buttar, M.H. (2015). Formation of Entrepreneurial Career Intentions: The Role of Sociocognitive Factors. Journal of Employment Counselling. 52(1):2-17.

Central Bank of Lesotho. (2015). Lesotho Macroeconomic Outlook 2014-2017. Available online, http://.www.centralbank.org.ls/.../Economic\%20Outlook/Lesotho\%20Economic\%20O.[Accessed: 2019-0605]

Cohen, L., Manion, L. \& Morrison, K. (2007).Research Methods in Education $6^{\text {th }}$ ed. Routlege: USA \& Canada

Council of Higher Education. (2017). The Higher Education Statistical Bulletin 2014/15. Available online, https://www.che.ac.ls/wp-content/uploads/2019/02/HE-Statistical-Bulletin-2014-15.pdf [Accessed: 2019-0905].

Damane, M. \&Sekantsi, L.P. (2018). The sources of unemployment in Lesotho, Modern Economy, 9:937-965

D'Silva, J.L., Shaffril, H.A.M., Uli, J., \&Samah, B.A. (2010). Socio-demographic factors that influence youth attitude towards contract farming, American Journal of Applied Sciences, 7(4):603-608

Ekpoh, U.I. \&Edet, A.O. (2011). Entrepreneurship Education and career intentions of tertiary education students in AlwaIbom and Cross River States, Nigeria, International Education Studies, 4(1):172-178

Gwary, M.M., Kwaghe, P.V., Ja'afar-Furo, M.R. \& Dennis, A. (2011). Analysis of entrepreneurial agricultural activities of youths in Michika Local Government Area of Adamawa State, Nigeria, Journal of Development and Agricultural Economics, 3(3):91-97

Idogho, P.O. \&Augustine, B.A. (2011). Entrepreneurship education and small-scale business management skill development among students of Auchi Polytechnic Auchi, Edo State, Nigeria, International Journal of Business Management, 6(3):284-288

Liñán, F. (2004).Intentions-Based Models of Entrepreneurship and Education. Available online, http://www.researchgate.net/publication/235937886 [Accessed: 2019-02-14]. 1-30

Nieman, G. \&Nieuwenhuizen, C. (2009). Entrepreneurship: A South African Perspective. $2^{\text {nd }}$ ed. Van Schaik. Pretoria.

Nishantha, B. 2009. Influence of personality traits and socio-demographic background of undergraduate students on motivation for entrepreneurial career: The case of Sri Lanka. Ryukoku Univ. Dep. Bull. Pap, 49(2): 71-82

Nor, N.A.A.M., Masdek, N.R.N.M. \&Maidin, M.K.H. (2015). Youth inclination towards agricultural entrepreneurship, Economic and technology Management Review, 10a:47-55)

Oyewuni, A. \&Olufemi, A.S. (2013).Assessing attitude to and knowledge of entrepreneurship among students with hearing impairment in Nigeria.An International Multidisciplinary Journal, Ethiopia, Serial No. 30:7(3):127142

Radipere, S. (2012). South African university entrepreneurship education, African Journal of Business Management, 6(44):11015-11022

Rauch, A. \&Hulsink, W. (2015). Putting entrepreneurship education where the intention to act lies: an investigation into the impact of entrepreneurship education on entrepreneurial behavior. Academy of Management Learning \& Education. 14(2):187-204

Ridha, R.N., Burhanuddin.,\&Wahyu, B.P. (2017). Entrepreneurship intention in agricultural sector of young generation in Indonesia.Asia Pacific Journal of Innovation and Entrepreneurship. 11(1):76-89

Ridha, R.N., Wahyu, B. \&Wahyu, B.P. (2017). Entrepreneurship intention in agricultural sector of young generation in Indonesia, Asia Pacific Journal of Innovation and Entrepreneurship, 11(1):76-89

Rocchi, A. \& Del Sette, P. (2016). Lesotho: rural Development and Migration-Centro Salute Global. Available online, http://www.centrosaluteglobale.eu/.../Migration_and-Rural-Development-in-Lesotho-pdf.pd. [Accessed: 2019-09-05].

Sa'adiah, T.B.T.H., Mahshar, M., Sulai, N.Y.A., Rosli, F., \&Hamzah, N.M. (2019).Factors influencing inclination towards Afro-Food entrepreneurship among Kelantan youth. Canadian Social Science, 15(5): 48-51

Sekaran, U. \&Bougie, R. (2013).Research methods for business: a skill-building approach. $6^{\text {th }}$ ed. United Kingdom: John Wiley \& Sons Ltd.

Shale, M. (2013).Unemployment biggest problem for Basotho, who also endorse illegal migration to get jobs.Afro Barometer Briefing Paper no.119.Available online, https://www.afrobarometer.org/sites/default/files/publications/.../afrobriefno119.pdf.[Accessed: 2019-07-05].

Sichone, T. \&Kwenye, J.M. (2018). Rural participation in Agriculture in Zambia.Journal of Agriculture Extension, 22(2):51-61

Sullivan, P. (2017). Agri-entrepreneurs and their characteristics, Available online, http://Cab.presswarehouse.com/sites/styles/resrcs/chapter/1780647759-1stchapetr.pdf. [Accessed: 2018-0912]. 1-17

Tamizharasi, G. \&Panchanatham, N. (2010).An empirical study of demographic variables on entrepreneurial attitudes.International Journal of Trade, Economics and Finance, 1(2),:215-220 
Tshikovhi, N. \&Shambare, R. (2015).Entrepreneurial knowledge, personal attitude, and entrepreneurship intentions among South African Enactus students.Problems and Perspectives in Management, 13(1):152-158

Uli, J., D'Silva, J.L., Shaffril, H.A.M. \&Samah, B.A. (2010). The attitude, belief, support and knowledge level of the youth and their acceptance towards agriculture contract farming, Journal of Social Sciences, 6(3):350-355

UNDP.(2012). Lesotho Youth Empowerment Survey. Available online, https://www.undp.org/content/dam/lesotho/.../Lesotho\%20Youth\%20ReportFinal.pdf?...[Accessed: 2019-07$05]$.

UNDP. (2017). Lesotho Country Analysis, working document: Final draft. Available online, https://.www.undp.org/.../lesotho/.../Lesotho\%20CCA_Final\%20Draft_22\%20September\%20 [Accessed: 2019-07-05]. 